\title{
Galba truncatula and Omphiscola glabra (Gastropoda, Lymnaeidae): present decline in populations living on sedimentary soils in central France
}

\author{
Gilles Dreyfuss ${ }^{*}$, Philippe Vignoles and Daniel Rondelaud \\ Laboratory of Parasitology, Faculty of Pharmacy, University of Limoges, 87025 Limoges, France
}

Received: 9 May 2017; Accepted: 12 December 2017

\begin{abstract}
Field investigations in habitats colonized by Galba truncatula or Omphiscola glabra were carried out to determine if the number of habitats, their area and the number of overwintering snails had not changed over the past 20 years. These habitats were studied in 57 cattle- or sheep-breeding farms located in three French natural regions on sedimentary soils. Compared to the numbers of snail habitats recorded before 1998, the values observed in 2016-2017 were significantly lower, with an overall decline rate of 30\% for G. truncatula and $38 \%$ for O. glabra. Variations in this decline rate were noted with the type of snail habitat and the largest decreases were observed for vernal pools in meadows. Significantly lower areas in 2016-2017 were noted in two habitat types (drainage furrows, road ditches) for G. truncatula and two other habitat types (drainage furrows, pond banks) for O. glabra. Significantly lower densities of overwintering snails were observed in 2016-2017 in G. truncatula habitats located in drainage furrows and road ditches, while no significant difference was noted for O. glabra, whatever the habitat type. Several causes were at the origin of this population decline and the most important were the present development of mechanical cleaning in road ditches, that of subsurface drainage in meadows and regular gyro-crushing of vegetation around pools in meadows. The data reported in this study confirm the decline that several authors have already noted for $O$. glabra in Western Europe. The results obtained for G. truncatula require reviewing the biogeographical status of this species and taking possible measures to ensure its conservation while taking into account its role as intermediate host in the F. hepatica cycle.
\end{abstract}

Keywords: Decline rate / Galba truncatula / habitat / Omphiscola glabra / sedimentary soils / snail density

\section{Introduction}

Two species of Lymnaeidae, i.e. Galba truncatula (O.F. Müller) and Omphiscola glabra (O.F. Müller), act as intermediate hosts in the transmission of human and animal fasciolosis. The former species is known to be the main snail host of Fasciola hepatica (Linnaeus) in Western European countries (Torgerson and Claxton, 1999; Mas-Coma et al., 2009a). In contrast, O. glabra is an occasional intermediate host whose role was mainly demonstrated on acid soils in the French region of Limousin (Abrous et al., 1999, 2000). Identifying habitats colonized by either lymnaeid, determining their area and counting overwintering snails are needed to set up an integrated control of fasciolosis on livestock and the host snail living in a farm (Mage et al., 1989).

As other native plant and animal species, these lymnaeids are exposed to all kinds of threats that vary between species

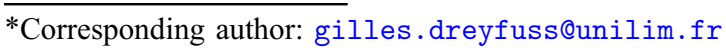

and populations. The causes of threats are multiple and the most common are degradation of snail habitats, predation by introduced animals, pollution or climate change (Government of South Australia, 2014). Land snails, slugs and bivalves are also vulnerable to this endangerment in the near future. One third of the malacofauna living in Ireland, for example, is, at present, under threat of extinction according to the recent Irish Red List of threatened species (National Biodiversity Data Centre of Ireland, 2016). According to the IUCN Red Lists of threatened species, the conservation status of both lymnaeids was not the same. Omphiscola glabra is assessed as critically endangered in the Republic of Ireland, endangered in Germany, and vulnerable in Great Britain, the Netherlands and Sweden (Prié et al., 2011). This classification is based on the generalized decline in the number and size of $O$. glabra populations that several authors have reported in Western Europe (Jackiewicz, 1999; Byrne et al., 2009; Welter-Schultes, 2012, 2013). In contrast, $G$. truncatula is a widespread species and no specific threats exist at the global level, as this snail is tolerant to pollution 
Table 1. Distribution of the 57 cattle- and sheep-breeding farms studied in three French departments on sedimentary soils according to their geographical location, the type of raised ruminant and the number of lymnaeid habitats.

\begin{tabular}{|c|c|c|c|c|c|}
\hline French department & Cantons * & \multicolumn{2}{|c|}{ Number of farms } & \multicolumn{2}{|c|}{ Number of snail habitats (first series of surveys) } \\
\hline \multirow[t]{2}{*}{ Eastern Charente } & Chasseneuil sur Bonnieure & 3 & 3 & 37 & 34 \\
\hline & La Rochefoucauld & 3 & 2 & 41 & 23 \\
\hline \multirow[t]{2}{*}{ Southern Indre } & Argenton sur Creuse & 3 & 2 & 19 & 13 \\
\hline & Saint Gaultier & 9 & 3 & 143 & 76 \\
\hline Totals & - & 24 & 33 & 483 & 269 \\
\hline
\end{tabular}

\footnotetext{
${ }^{*}$ French administrative subdivision grouping several municipalities.
}

and is known as a colonizing species in many temporary habitats (Seddon et al., 2015).

As no study had been carried out in France before 2013 to assess the conservation status of both lymnaeid populations, field investigations were carried out from 2013 to 2016 to determine the number and size of G. truncatula and O. glabra populations in 162 cattle- or sheep-breeding farms located on acid soils in the Limousin region (Dreyfuss et al., 2016). According to these authors, an overall decline of $34 \%$ in the number of $G$. truncatula habitats and $23.4 \%$ in $O$. glabra habitats has been noted over the past 20 years. The size of lymnaeid populations was also affected because overwintering snails were significantly fewer in five habitat types for $G$. truncatula and three only for O. glabra. In contrast, the distribution of these habitats depending on their area did not show any significant change over time (Dreyfuss et al., 2016). In view of these preliminary findings, it was interesting to check their validity in several other French natural regions through the following two questions: did the lymnaeid habitats located on sedimentary soils also show a decline in their number? Did their characteristics (habitat area, size of snail populations) show any change over time? To answer these questions, a comparative study between the results coming from two series of investigations was performed. The first was carried out from 1986 to 1997 in 57 farms located on sedimentary soils in three French departments, i.e. Charente, Indre and Vienne. The second series was performed in 2016 and 2017 in the same farms.

\section{Materials and methods}

\subsection{Farms investigated}

From 1986 to 1997, an outbreak of fasciolosis has been detected in cattle or sheep by veterinarians in 57 farms located in three departments of central France: Charente (11 farms), Indre (17) and Vienne (29). These farms are located in natural regions close to the cristallophyllian and metamorphic soils of Limousin (Tab. 1 and Fig. 1), and their altitude ranges from 80 to $145 \mathrm{~m}$ above sea level. Because of the nature of soils, the $\mathrm{pH}$ of running water ranges from 6.8 to 8.1 and the level of dissolved calcium is generally between 28 and $41 \mathrm{mg} / \mathrm{L}$ (unpublished data). All permanent pastures present in these farms are hygro-mesophilous and are subjected to an alternate regime of grazing and mowing. An open drainage network is

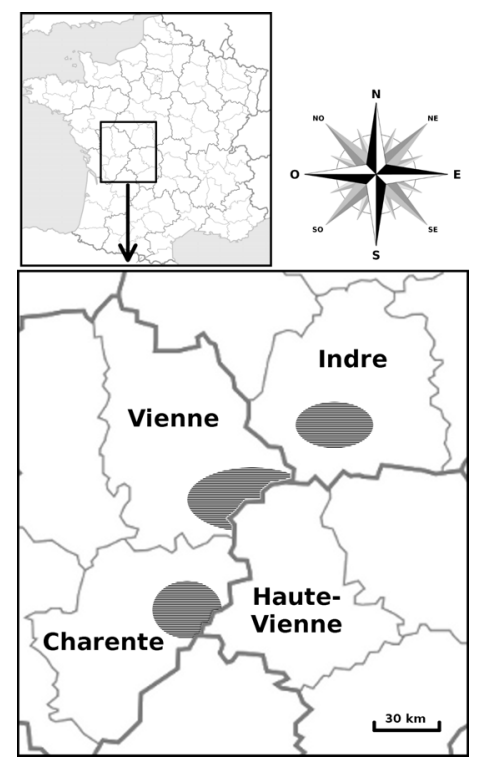

Fig. 1. Location of the departments surveyed in central France (upper map) and zones (hatched areas) in which the 57 farms are located (lower map).

generally present in most pastures; in the others, the evacuation of rainwater is only ensured by one or two furrows. All are subjected to a mild oceanic climate modulated by moist winds from the Atlantic Ocean. According to years, average annual rainfall ranged from 750 to $850 \mathrm{~mm}$, while the average annual temperature ranged from $11.5^{\circ} \mathrm{C}$ to $12.5^{\circ} \mathrm{C}$ on most pastures (Observatoire Régional de l'Environnement Poitou-Charentes, 2017).

In these 57 farms, no change in livestock farming was noted between the two series of investigations, at least over the past twenty years.

\subsection{Protocol of investigations}

From 1986 to 1997, we have investigated the entire area of each farm to examine water holes in permanent meadows and road ditches, which lined them, for snail presence. This was also done on the banks of evacuation systems, i.e. ponds, streams and rivers. The total area investigated on these 57 
Table 2. Number of habitats with Galba truncatula or Omphiscola glabra in the 57 farms before 1998 and in $2016-2017$ in relation to their type.

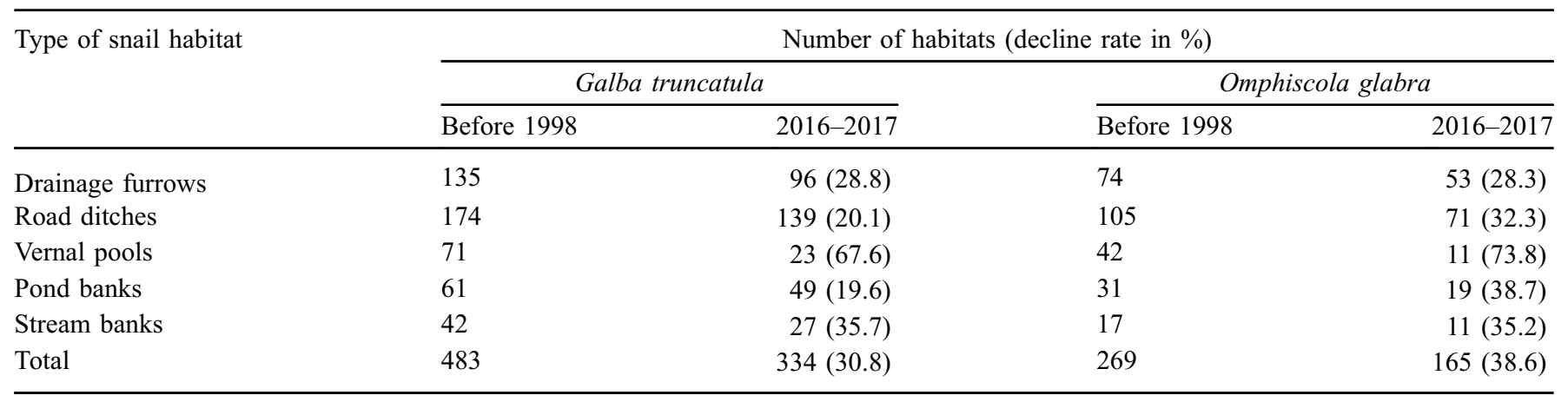

farms was $54.6 \mathrm{~km}^{2}$. We have studied these water holes in March or April because all were waterlogged. In each hole where $G$. truncatula or $O$. glabra was living, the population was evaluated by counting adults (more than $4 \mathrm{~mm}$ shell height for G. truncatula, $12 \mathrm{~mm}$ for O. glabra), as all belonged to overwintering generations. Each snail count was carried out by two persons for $30-40 \mathrm{~min}$ (snail habitats in permanent meadows) or a single person for 15-20 min (road ditches, pond banks, stream banks). The area of each habitat with alive snails was then determined. Measurement of areas occupied by $G$. truncatula or O. glabra was easy in the case of furrows, ditches, ponds and streams. The habitats located around/in vernal pools in meadows were mapped and their area was determined according to their geometrical shape and their dimensions.

We re-investigated these 57 farms in 2016 or 2017 (i) to redetect snail habitats, (ii) to identify lymnaeid species, (iii) to measure the area of each snail habitat and (iv) to count overwintering snails. This was done in March or April on the entire area of each farm. The farmer was also asked to determine the cause of lymnaeid disappearance when the habitats of either species have not been found.

\subsection{Types of snail habitats}

We have considered five types of snail habitats for either lymnaeid. The first two were located in meadows: (i) surface drainage furrows and (ii) vernal pools $\left(<20 \mathrm{~m}^{2}\right.$ in surface area) with or without a temporary spring. The other three types were (iii) road ditches when waterlogged during winter and spring, (iv) small streams, and (v) the banks of large ponds near their inlet. The vegetation around the drainage ditches and permanent pools was mainly composed of plants belonging to the Poaceae family, with rare clumps of rushes. On the other hand, the rushes were more abundant in the road ditches as on the banks of streams and ponds.

In the drainage furrows, vernal pools and road ditches, summer drying generally occurred from mid-June to the end of November. In contrast, its length was shorter in habitats on stream and pond banks: from late June up to mid-October.

\subsection{Parameters studied}

These parameters were (i) the number of habitats occupied by snails, (ii) the area of each habitat and (iii) the density of overwintering snails per $\mathrm{m}^{2}$ of habitat. To determine the distribution of $G$. truncatula habitats in relation to their size, we have classified individual values as follows: up to $1 \mathrm{~m}^{2}$, from 1.1 to $2 \mathrm{~m}^{2}$, from 2.1 to $3 \mathrm{~m}^{2}, 3.1$ to $4 \mathrm{~m}^{2}$, and $>4 \mathrm{~m}^{2}$. In the case of $O$. glabra, the areas were classified into the following five categories: up to $2 \mathrm{~m}^{2}$, from 2.1 to $5 \mathrm{~m}^{2}$, from 5.1 to $10 \mathrm{~m}^{2}$, from 10.1 to $20 \mathrm{~m}^{2}$, and $>20 \mathrm{~m}^{2}$. Similarly, the distribution of habitats in relation to snail densities was studied using four categories for $G$. truncatula $\left(\leq 10 \mathrm{snails} / \mathrm{m}^{2}\right.$, from 10.1 to $25 / \mathrm{m}^{2}$, from 25.1 to $40 / \mathrm{m}^{2}$, and $>40 / \mathrm{m}^{2}$ ) and four others for $O$. glabra $\left(\leq 5 \mathrm{snails} / \mathrm{m}^{2}\right.$, from 5.1 to $10 / \mathrm{m}^{2}$, from 10.1 to $15 / \mathrm{m}^{2}$, and $\left.>15 / \mathrm{m}^{2}\right)$. These area and density categories were determined during other snail investigations on acid soils (Rondelaud et al., 2011; Vignoles et al., 2017). This distribution of habitats into classes according to their area and their density in snails was preferred here to the calculation of mean areas and mean densities because these classes enable to limit the influence of extreme dispersions and more easily detect any change between the two periods of investigations.

The numbers of sites occupied by snails in the 57 farms before 1998 and in 2016 or 2017 were compared using Fisher's exact test. The distributions of these sites according to their area or their density of overwintering snails were compared using the same test. In each case, we used the fisher.multcomp of the RVAideMemoire package (R Core team, 2016) as a posthoc test to do pairwise comparisons. All these analyses were performed using the R 3.3.0 software (R Core Team, 2016).

\section{Results}

\subsection{Number of snail populations}

Of the 483 habitats of $G$. truncatula investigated before 1998 (Tab. 2), only 334 were found in 2016 or 2017, corresponding to an overall decline of $30 \%$. However, this decline in the number of snail habitats was not uniform and varied according to the habitat type. The largest decline rate was observed for habitats in vernal pools $(67 \%)$, followed by those on brook banks (35\%) and in drainage furrows $(28 \%)$. The lowest decreases were observed for habitats in road ditches $(20 \%)$ and on pond banks (19\%). A significant difference $(p<0.01)$ between the decline rates of the five types of habitats was noted. The decrease in the number of habitats in pools was significantly higher than those observed in drainage furrows, road ditches and pond banks. The differences between the other habitat types were not significant. 

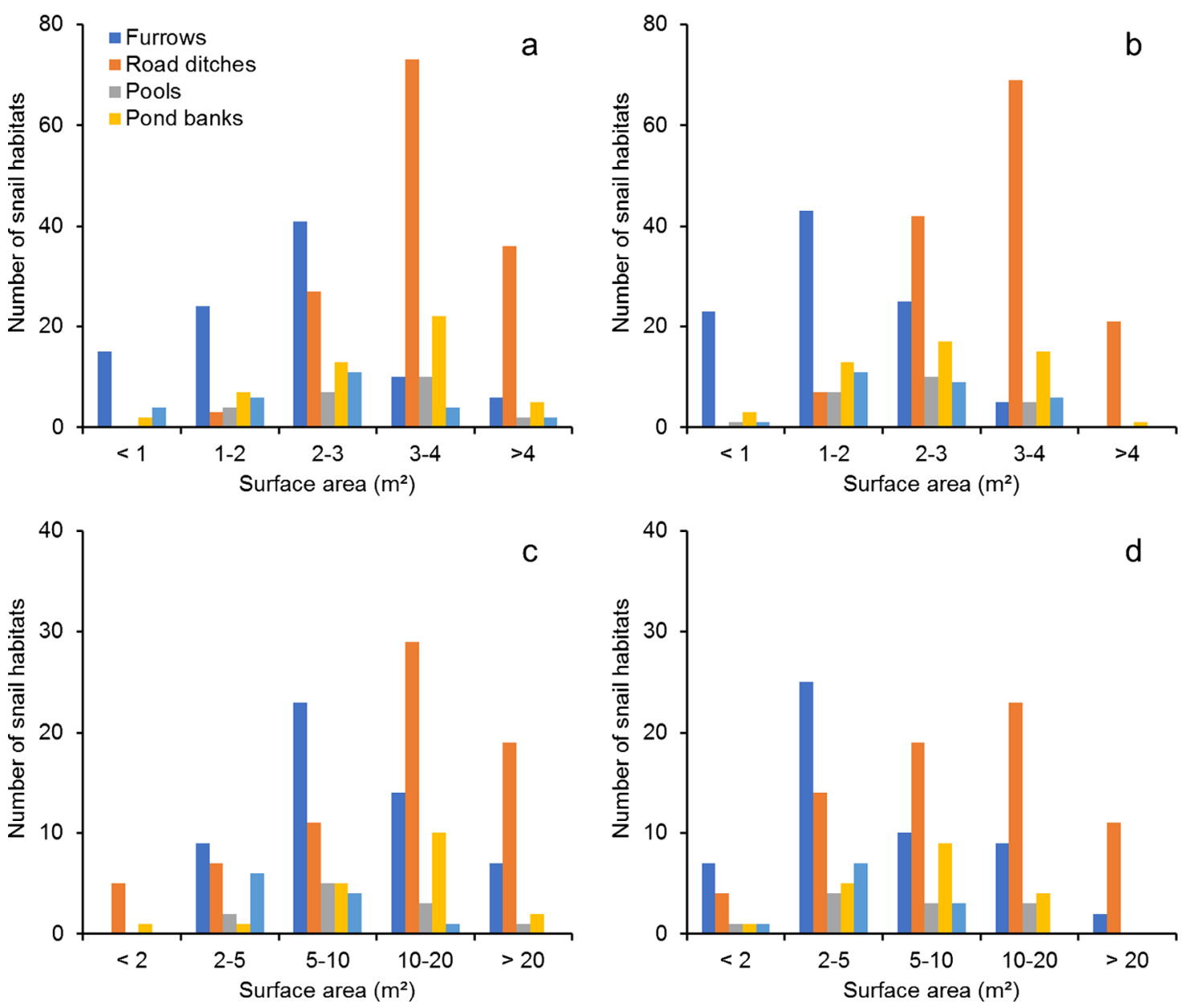

Fig. 2. Distribution of 334 populations for Galba truncatula and 165 for Omphiscola glabra observed in the 57 farms according to the surface area of their habitat in March or April: G. truncatula before 1998 (a) and in 2016-2017 (b), O. glabra before 1998 (c) and in $2016-2017$ (d). The total number of populations in 2016-2017 is given in Table 2 for each habitat type.

In the case of $O$. glabra (Tab. 2), we noted a total of 165 habitats with alive snails in 2016-2017 out of the 269 detected before 1998, so that the overall rate of decline between these two periods was $38 \%$. The highest decline rate was recorded in vernal pools $(73 \%)$ and the lowest in drainage furrows $(28 \%)$. In the other three habitat types, the rates of decrease ranged from $32 \%$ to $38 \%$. Although the decrease in the number of habitats located in vernal pools was higher than those observed in the other habitat types, the difference between these decline rates was not significant.

No significant correlation between these decreases in the number of habitats occupied by snails and the department, where the farms are located, or the type of ruminants (cattle or sheep) was noted.

\subsection{Area of snail habitats}

Figure 2 shows the distribution of 334 habitats for $G$. truncatula and 165 for $O$. glabra according to their area before 1998 and in 2016-2017. Compared to values noted before 1998, the surface areas noted in 2016 or 2017 (Fig. 2a, b) were significantly decreased in $G$. truncatula habitats located in drainage furrows $(p<0.001)$ and road ditches $(p<0.05)$. In the other three habitat types, the differences between these two periods were not significant. In the case of $O$. glabra (Fig. 2c, d), significantly lower values for snail habitats in drainage furrows $(p<0.001)$ and on pond banks $(p<0.05)$ were noted in 2016-2017, while the differences between the other three habitat types were not significant.

\subsection{Number of overwintering snails}

Figure 3 shows the distribution of snail densities according to the number of overwintering snails counted before 1998 and in 2016-2017. In the case of G. truncatula (Fig. 3a, b), snail densities recorded in 2016-2017 were significantly lower in habitats located in drainage furrows $(p<0.001)$ and road ditches $(p<0.05)$ than values noted before 1998, while differences between the other three habitat types were not significant. In contrast, no significant differences in snail densities between 1998 and 2016-2017 were noted for $O$. glabra, whatever the habitat type (Fig. 3c, d). 

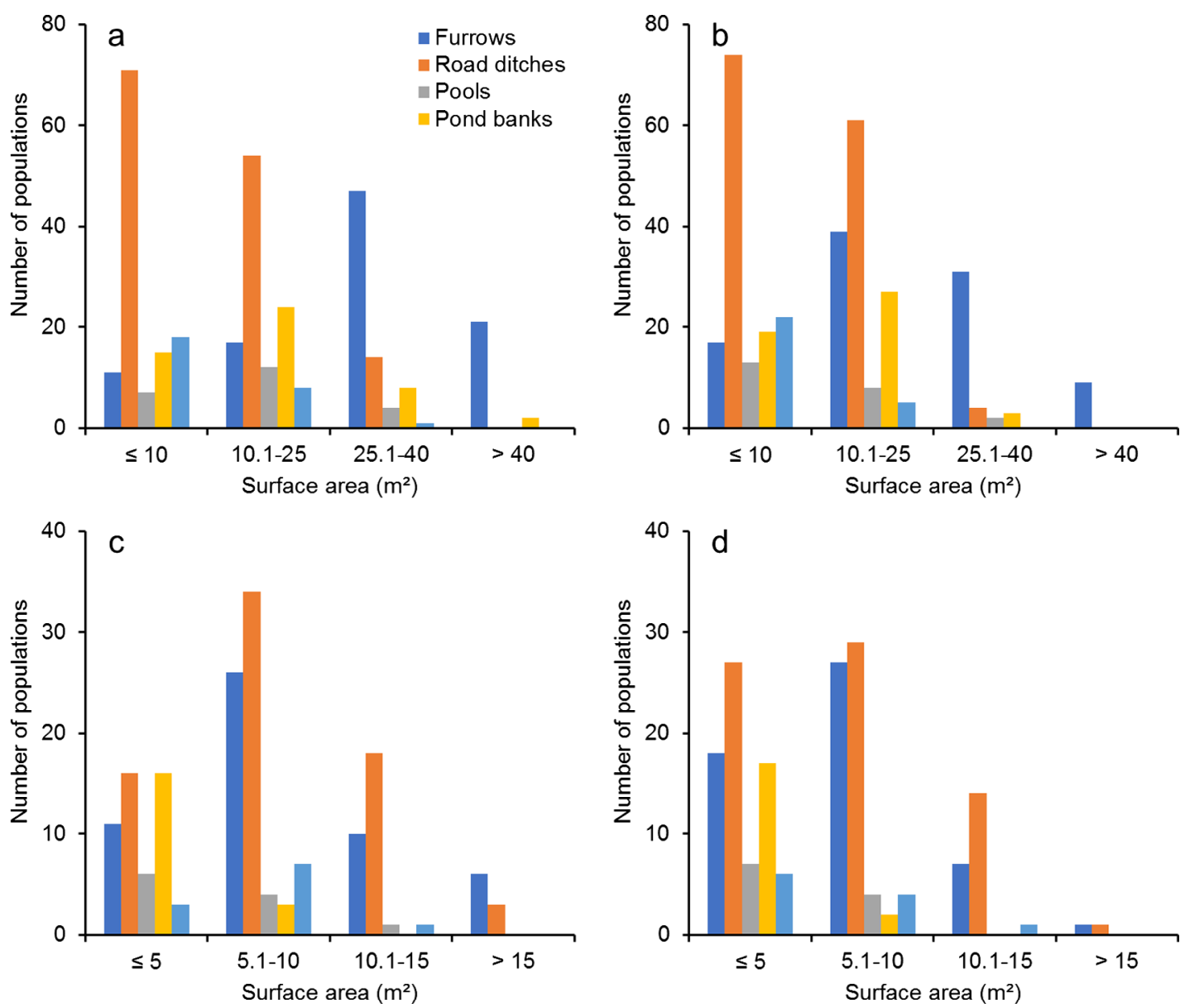

Fig. 3. Distribution of 334 populations for Galba truncatula and 165 for Omphiscola glabra observed in the 57 farms according to the density of their overwintering snails in March or April: G. truncatula before 1998 (a) and in 2016-2017 (b), O. glabra before 1998 (c) and in $2016-2017$ (d). The total number of populations in 2016-2017 is given in Table 2 for each habitat type.

Table 3. Number of snail habitats disappeared in 2016-2017 in relation to the cause of population decline and the type of habitat. A/B, sites inhabited by Galba truncatula/sites inhabited by Omphiscola glabra.

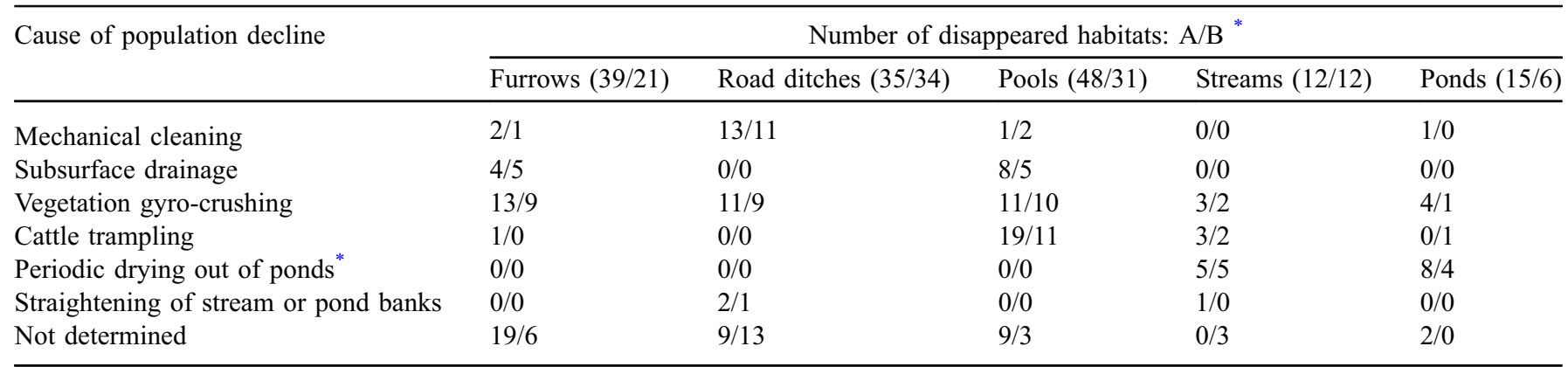

\footnotetext{
${ }^{*}$ Usually every three years.
}

\section{Discussion}

On sedimentary soils, both lymnaeid species have shown a current decrease in the number of their populations over time. Moreover, this decline rate varied according to snail species and habitat type. The disappearance of 149 habitats for G. truncatula and 104 for $O$. glabra over the past 20 years is due to several causes which are presented in Table 3. The most frequent cause in drainage furrows, road ditches and vernal pools was vegetation gyro-crushing, as this technique was frequently used by 27 farmers between 1998 and 2016-2017 to destroy rush clumps around ditches, pools and in road ditches. As the technique was generally applied in early July, the absence of vegetation around/ in snail habitats had a negative effect on the survival of snails 
during summer drying. Another cause was the mechanical cleaning of road ditches, as this technique is increasingly used in grasslands and road ditches by herders and/or local administrative authorities in central France (Rondelaud et al., 2009; Dreyfuss et al., 2015). Cattle trampling also was the main cause for the disappearance of snail habitats in vernal pools, as these water bodies are still used by animals for their water needs, despite the presence of artificial reservoirs in the pastures since the 2000s (Rondelaud et al., 2009; Dreyfuss et al., 2015). The other causes listed in Table 3 are of minor importance. On the other hand, the cause of snail disappearance was not specified for 37 habitats for G. truncatula and 22 for O. glabra in drainage furrows, road ditches and vernal pools. We suggest that this snail disappearance might be due to the effects of global warming from the 2000s because the latter is known to act on animal or plant biodiversity (Root et al., 2003; Stewart, 2009). In addition, this increase in temperature has a disruptive effect on snails which intervene as intermediate hosts in the transmission of several helminthoses (Mas-Coma et al., 2008, 2009b). An argument supporting this approach is the total drying of many pools occurred in recent years in the French departments of Indre and Vienne, whatever the time of the year (D. Rondelaud, personal observation). In the present study, the disappearance of populations over the past 20 years was greater in O. glabra (38\%) than in G. truncatula (30\%). This finding disagreed with the report by Dreyfuss et al. (2016) on the populations of the two lymnaeids living on acid soils. According to these authors, the overall decline in the number of habitats was $34 \%$ for $G$. truncatula and $23 \%$ for O. glabra between 1976-1992 and 2013-2016. To explain this difference, the most reliable hypothesis is that $O$. glabra populations would be less resistant to unfavourable conditions than those of G. truncatula when they live on sedimentary soils. This hypothesis is supported by the following observations: (i) the populations of O. glabra were more numerous on the cristallophyllian soils of central France than in the surrounding sedimentary regions (Vignoles et al., 2017) and this distribution is consistent with the report by Boycott (1936), as the species prefers to live on slightly acid soils; (ii) the habitats of $O$. glabra were larger than those of G. truncatula (Fig. 2) in the studied areas and the vegetation around them was often grassy, which protects them poorly from the effects of the sun during summer drying, even if $O$. glabra is able to withstand this drying by burying in the soil (Rondelaud et al., 2003); (iii) the amphibiosis of $G$. truncatula allows it to adapt to degraded life conditions, while $O$. glabra is more aquatic (Taylor, 1965).

In 2016-2017, the mean area of habitats colonized by $G$. truncatula was significantly lower in drainage ditches and road ditches. The same finding was noted for O. glabra, but for habitats in drainage ditches and pond banks. These results disagreed with the observations of Dreyfuss et al. (2016) in habitats on acid soils because they did not note any significant variation in the habitat areas of each lymnaeid considered separately. This difference between our results and those of the above authors is difficult to explain. The dates on which habitats were investigated in 2016 or 2017 , and, consequently, weather conditions can not alone explain this discrepancy because these area-reduced habitats were noted throughout the survey period (March or April) for the two years. The most valid explanation is to relate this difference to properties (moisture, texture, drying conditions) of soils present in sedimentary or acid regions and local climatic conditions. Indeed, the average annual temperature in the studied areas varied from $11.5^{\circ} \mathrm{C}$ to $12.5^{\circ} \mathrm{C}$ (Observatoire Régional de l'Environnement Poitou-Charentes, 2017), whereas it was between $10^{\circ} \mathrm{C}$ and $11^{\circ} \mathrm{C}$ on acidic soils in Limousin (CRPF Limousin, 2010). Similarly, annual precipitation ranged from 750 to $850 \mathrm{~mm}$ depending on the area in the sedimentary regions and from 900 to $1000 \mathrm{~mm}$ in most communes of Limousin.

Contrary to lymnaeid habitats on acid soils, the numbers of overwintering $G$. truncatula in sedimentary regions have significantly decreased in two types of habitats (drainage furrows, road ditches). On the other hand, no significant variation in the numbers of $O$. glabra was recorded between the two study periods, whatever the habitat type. These results disagreed with the observations of Dreyfuss et al. (2016) on acid soils, as these authors reported a decline in numbers in five habitat types for $G$. truncatula and only three types for O. glabra. Two explanations have already been proposed by Dreyfuss et al. (2016) to explain this decrease: (i) the occurrence of iridovirosis in the case of $G$. truncatula (this epizooty has not yet been observed in O. glabra), as that noted in Limousin (Barthe et al., 1984; Rondelaud and Barthe, 1992); (ii) the development of vegetation surrounding the habitat at more advanced stages in response to favourable climatic and hydrological conditions, leading to a limitation or loss of algal cover on which the snails feed (Moens, 1981, 1991). But this decline in snail numbers in several populations may also be simply a consequence of human activity (repeated passages of tractors, vegetation gyro-crushing, ...) or of animals (cattle trampling, ...) especially on pastures, as already reported for snail populations living on acid soils (Rondelaud, 1977).

At the present time, it is difficult to determine the consequences that the disappearance of several snail populations may have on the prevalence of fasciolosis in a farm. Two facts support this assertion. First, the use of triclabendazole to treat cattle against this parasitosis has become widespread in central France from the 2000 s, which led to a gradual decrease in the prevalence of the disease in ruminants and, consequently, in the number of snails naturally infected with $F$. hepatica (Dreyfuss et al., 2016). Second, most farmers involved in the present study used rotational grazing for their ruminants in relation to vegetation growth throughout the year, which does not allow for an accurate study because the habitats disappeared over the past 20 years were located on different pastures and were often adjacent to other habitats with alive G. truncatula or alive $O$. glabra.

In central France, the two species of lymnaeids show a general decline in the number of their populations, whatever the geological nature of the subsoil. In habitats on sedimentary soils, there is also a reduction in area for two habitat types and a decrease in the number of overwintering snails for two other habitat types. The data reported in this study confirm the decline that several authors such as Byrne et al. (2009), Prié et al. (2011) or Welter-Schultes (2013) noted for O. glabra in other European countries. On the other hand, the results obtained for G. truncatula in the report by Dreyfuss et al. (2016) and in this study require reviewing the biogeographical status of this species and taking possible measures to ensure its conservation while taking into account its role as intermediate host in the F. hepatica cycle. 
Acknowledgements. The authors gratefully thank the 57 farmers for having provided easy access to the sampling sites and assistance during this survey.

\section{References}

Abrous M, Rondelaud D, Dreyfuss G, Cabaret J. 1999. Infection of Lymnaea truncatula and Lymnaea glabra by Fasciola hepatica and Paramphistomum daubneyi in farms of central France. Vet Res 30: 113-118.

Abrous M, Rondelaud D, Dreyfuss G. 2000. A field study of natural infections in three freshwater snails with Fasciola hepatica and/or Paramphistomum daubneyi in central France. J Helminthol 74: 189-194.

Barthe D, Rondelaud D, Faucher Y, Vago C. 1984. Infection virale chez le Mollusque Pulmoné Lymnaea truncatula Müller. C R Hebd Seances Acad Sci D 298: 513-515.

Boycott AE. 1936. The habitats of freshwater Mollusca in Britain. $J$ Anim Ecol 5: 116-186.

Byrne A, Moorkens EA, Anderson R, Killeen IJ, Regan EC. 2009. Ireland Red List no. 2: Non-marine molluscs. Dublin: National Parks and Wildlife Service, Department of the Environment, Heritage and Local Government, 49 p.

CRPF Limousin. 2010. Le climat en Limousin. Available at: http:// www.crpf-limousin.com/sources/files/FOGEFOR/botafor_climat limousin.pdf (Accessed on 2017/30/03).

Dreyfuss G, Vignoles P, Rondelaud D. 2015. The mud snail (Galba truncatula). Ecology, parasitism and control. Saarbrücken: Lambert Academic Publishing, 243 p.

Dreyfuss G, Vignoles P, Rondelaud D. 2016. Present decline in the number and size of Galba truncatula and Omphiscola glabra populations, intermediate hosts of Fasciola hepatica, on the acidic soils of Central France. Parasite 23: 46.

Government of South Australia. 2014. Managing natural resources, by the Department of Environment, Water and Natural Resources. Available at: http://www.environment.sa.gov.au/managing-natu ral-resources (Accessed on 2016/03/11).

Jackiewicz M. 1999. Phylogeny and relationships within the European species of the family Lymnaeidae (Gastropoda: Pulmonata: Basommatophora). Folia Malacol 5: 61-95.

Mage C, Reynal P, Rondelaud D, Chasteloux C. 1989. Mise en pratique du contrôle de l'infestation par Fasciola hepatica chez des bovins limousins. Bull Group Tech Vét 347: 5-10.

Mas-Coma S, Valero MA, Bargues MD. 2008. Effects of climate change on animal and zoonotic helminthiases. Rev Sci Tech Off Int Epiz 27: 443-452.

Mas-Coma S, Valero MA, Bargues MD. 2009a. Fasciola, lymnaeids and human fascioliasis, with a global overview on disease transmission, epidemiology, evolutionary genetics, molecular epidemiology and control. Adv Parasitol 69: 41-146.

Mas-Coma S, Valero MA, Bargues MD. 2009b. Climate change effects on trematodiases, with emphasis on zoonotic fascioliasis and schistosomiasis. Vet Parasitol 163: 264-280.

Moens R. 1981. Les habitats de Lymnaea truncatula, hôte intermédiaire de Fasciola hepatica. Rev Agric (Brussels) 34: 1563-1580.
Moens R. 1991. Factors affecting Lymnaea truncatula populations and related control measures. J Med Appl Malacol 3: 73-84.

National Biodiversity Data Centre of Ireland, 2016. Ireland's snails threatened with extinction. Available at: http://www.heritagecoun cil.ie/wildlife/news/view-article/article/irelands-snails-threatenedwith-extinction/?cHash=76b7e8d809 (Accessed on 2016/09/09).

Observatoire Régional de l'Environnement Poitou-Charentes. 2017. L'eau en Poitou-Charentes: pluviométrie. Available at: http://www. eau-poitou-charentes.org/Pluviometrie.html (Accessed on 2017/ 30/03).

Prié V, Seddon MB, Vavrova L. 2011. Omphiscola glabra. The IUCN Red List of threatened species. Version 2015.2. Available at: http:// www.iucnredlist.org (Accessed on 2015/27/07).

R Core Team. 2016. R: a language and environment for statistical computing. Vienna: R Foundation for Statistical Computing. Available at: https://www.R-project.org (Accessed on 2016/27/ 06).

Rondelaud D. 1977. L'évolution démographique de Lymnaea (Galba) truncatula Müller en Haute-Vienne. A propos de quatre années d'observations. Ann Parasitol Hum Comp 52: 511-520.

Rondelaud D, Barthe D. 1992. Observations épidémiologiques sur l'iridovirose de Lymnaea truncatula, mollusque vecteur de Fasciola hepatica. C R Hebd Seances Acad Sci D 314: 609-612.

Rondelaud D, Vignoles P, Dreyfuss G. 2003. Field observations on the aestivation of Omphiscola glabra (Gastropoda, Lymnaeidae) uninfected or infected with Fasciola hepatica in central France. Ann Limnol-Int J Lim 39: 129-133.

Rondelaud D, Vignoles P, Dreyfuss G. 2009. La Limnée tronquée, un mollusque d'intérêt médical et vétérinaire. Limoges: PULIM, 283 p.

Rondelaud D, Hourdin P, Vignoles P, Dreyfuss G, Cabaret J. 2011. The detection of snail host habitats in liver fluke infected farms by use of plant indicators. Vet Parasitol 181: 166-173.

Root LR, Price JT, Hall KR, Schneider SH, Rosenzweig C, Pounds JA. 2003. Fingerprints of global warming on wild animals and plants. Nature 421: 57-60.

Seddon MB, Kebapçı U, Van Damme D. 2015. Galba truncatula. The IUCN Red List of Threatened Species 2015: e. T155730A85693575. Available at: http://dx.doi.org/10.2305/ IUCN.UK.2015.RLTS.T155730A85693575.en (Accessed on 2016/28/01).

Stewart SJ. 2009. Adapting to climate change: implications for freshwater biodiversity and management in the UK. Fresh Rev 2: 51-56.

Taylor EL. 1965. Fasciolia-sis and the liver-fluke. Roma: FAO Agricultural Studies, no. 64, 235 p.

Torgerson P, Claxton J. 1999. Epidemiology and control. In: Dalton JP, ed. Fasciolosis. Oxon: CABI Publishing, 113-149.

Vignoles P, Dreyfuss G, Rondelaud D. 2017. Ecologie et parasitisme de la Limnée étroite (Omphiscola glabra). Limoges: PULIM, 228 p.

Welter-Schultes F. 2012. European non-marine molluscs. A guide for species identification. Göttingen: Planet Poster Editions, 760 p.

Welter-Schultes F. 2013. Species summary for Omphiscola glabra. Available at: http://www.animalbase.uni-goettingen.de/zooweb/ servlet/AnimalBase/home/species?id=2000 (Accessed several times from 2015/22/07 to 2016/20/01). 